\title{
Whole Blood Characterization in School Teachers with Reference to Chalk Sticks
}

\author{
Ramprasad S and Maruthi YA*
}

Department of Environmental Studies, GIS, GITAM University, Visakhapatnam, Andhra Pradesh, India

\begin{abstract}
It is known that usage of chalk causes dust and exposure to chalk dust can cause health hazards in teachers. But the level of exposure to chalk dust in teachers were not known so far. Hence, present study aimed to investigate the level of exposure to chalk dust in teachers by studying the whole blood concentrations of trace elements $(\mathrm{Al}, \mathrm{Cr}, \mathrm{Mn}, \mathrm{Fe}$, $\mathrm{Co}, \mathrm{Ni}, \mathrm{Si}, \mathrm{Pb}$ ) that are associated with chalk. ICPMS method was adopted to conduct the trace element concentration in whole blood and due to lack of reference standards, the recovery percentages were analyzed. From the results, it is identified that except Si all the elements are noticed beyond the normal blood limits in teachers. For silicon, there is no normal blood limit. The relation between the trace elemental concentration and socio demographic variables like gender, age, Years of service was also studied. The age and gender did not show significant difference with the trace element concentration. The years of service revealed a positive association with trace element concentrations. The elements like Si $(70847 \mu \mathrm{g} / \mathrm{l})$, Iron $(19499 \mu \mathrm{g} / \mathrm{l})$, Al $(1389.9 \mu \mathrm{g} / \mathrm{l})$ were noticed with elevated concentrations in teachers. The same elements were reported with higher concentrations in past studies that are conducted on trace elements concentration of chalk. Hence, it is proved that the chalk is the prime reason for the elevated concentrations of trace elements in blood and it also concluded that usage of chalk causes health hazards in teachers.
\end{abstract}

Keywords: Trace elements; Whole blood; Chalk

\section{Introduction}

In addition to the occupational health hazards in teachers [1], few recent studies suggested that chalk can also cause occupational health hazards in teachers [2]. It is proved that chalk will behave like particulate matter (PM) which remains suspended in air for longer period of time [3]. The writing exercises on chalk also revealed that chalk produces large amount of dust [4]. Few epidemiological studies reported that metals in the chalk dust causes allergic contact dermatitis [5] respiratory ailments [6,7]. Recent Experimental studies also proved that metals in chalk dust causes oxidative damages to Alveolar Macrophages [8-9].

Black board concept of teaching is an ancient method of teaching and many schools in India are still following this concept because of its economic viability $[10,11]$. Chalk composes of $\mathrm{CaCO}_{3}, \mathrm{CaSO}_{4} .2 \mathrm{H}_{2} \mathrm{O}$, additives like CMC (carboxyl methyl cellulose), PVA (poly vinyl alcohol), and starch which were used as thickeners, and water binders $\mathrm{ZnO}$, kaolinite, and colored pigments with standard grain size of these particles. The quality of chalk depends on the percentage of caco3 and its controlling variables like binders. Chalks with less than $6 \%$ of CMC are dusty [12]. Initially, chalk was known to be dusted chalks composed of calcium sulfate (gypsum). The dust particles released from these chalks tend to remain in air for longer period of time. Later on, many industries launched dustless chalks. These dustless chalks are made up of calcium carbonate with the binder in the chalk that releases dust with large particles, which are not respirable and settle faster [13]. These settled dust particles, which settles on body parts of teachers can also causes allergic infections [14]. Even though it is dusted or dustless chalk it is fact that it will cause health hazards in teachers $[15,16]$.

Predictable medium for assessment of exposure to toxic metals and essential trace elements are blood and urine. As an alternative substrates hair, Saliva, nails and in some rare cases even breast milk [17]. In the present study, blood is used as collective medium for exposure assessment.

In our previous studies, the concentration of trace elements in different brands on chalk was analyzed [18]. Later the trace elements in chalk dust collected from classroom were examined [19]. In the present study, the concentration of trace elements in the blood samples of teachers was analyzed using ICPMS.

\section{Materials and Methods}

\section{Sample collection}

With the collaboration from the few medical laboratories samples of teachers were collected. Among the visitors who came for blood examination the teachers were identified separately based on the occupation. All the information related to this work was explained to the teachers and with the consent of the teachers; the sample was collected and stored for further studies.

\section{Elemental analysis}

\section{Dilution process}

The collected samples were diluted by following the alkali dilution method [20]. Aliquot $(0.2 \mathrm{ml})$ of whole blood samples were diluted $1: 25$ with an alkali solution consisting of $2 \%(\mathrm{~W} / \mathrm{V}) 1$-butanol, $0.05 \%$ (W/V) EDTA, $0.05 \%(\mathrm{~W} / \mathrm{V})$ triton $\mathrm{X}-100,1 \%(\mathrm{w} / \mathrm{v}) \mathrm{NH}_{4} \mathrm{OH}$ and internal standards $20 \mu \mathrm{g} / \mathrm{L}$. The mixture was sonicated for 5 minutes and centrifuged at $1000 \mathrm{rpm}$ for 2 minutes.

\section{Experimental set up}

The Agilent 7700s inductively coupled plasma mass-spectroscopy

*Corresponding author: Maruthi YA, Department of Environmental Studies, GIS, GITAM University, Visakhapatnam-530045, Andhra Pradesh, India, Tel: +919440025015; E-mail: ymjournal2014@gmail.com

Received March 25, 2017; Accepted April 28, 2017; Published May 05, 2017

Citation: Ramprasad S, Maruthi YA (2017) Whole Blood Characterization in School Teachers with Reference to Chalk Sticks. J Environ Anal Toxicol 7: 465. doi: 10.4172/2161-0525.1000465

Copyright: ( 2017 Ramprasad S, et al. This is an open-access article distributed under the terms of the Creative Commons Attribution License, which permits unrestricted use, distribution, and reproduction in any medium, provided the original author and source are credited. 
Citation: Ramprasad S, Maruthi YA (2017) Whole Blood Characterization in School Teachers with Reference to Chalk Sticks. J Environ Anal Toxicol 7: 465. doi: 10.4172/2161-0525.1000465

Page 2 of 5

(ICP-MS) system (Agilent technologies, Tokyo, Japan) was engaged to assess the ion profile. Platinum sample cone and skimmer cone were utilized with an orifice diameter of 1.0 to $0.4 \mathrm{~mm}$, respectively. Sample introduction was performed with a micro mist nebulizer combined with scott-type double pass spray chamber (Agilent technologies).

The instrument was tuned to optical conditions in terms of sensitivity ( $\mathrm{Li}, \mathrm{Y}, \mathrm{Co}$ and $\mathrm{Ti}$ ) and $\mathrm{Ce} 0 / \mathrm{Ce}$ and $\mathrm{Ce} 2+/ \mathrm{Ce}$ by using a tuning solution (Agilent technologies) containing $1 \mathrm{mg} / \mathrm{L}$ of $\mathrm{Li}, \mathrm{Y}, \mathrm{Ti}, \mathrm{Ce}$ and $\mathrm{Co}$ in $2 \%$ $\mathrm{HNO}_{3}(\mathrm{~W} / \mathrm{V})$. The instrument was operated in full quantitative mode, and typical operating conditions used in this study are summarized in the Table 1.

\section{Validation of ICP-MS}

To validate the method, ten randomly selected blood samples of 0.2 $\mathrm{ml}$ mixed together and spiked with known concentrations. From the results, we have calculated percentage recoveries based on the following equation.

\section{Percentage recovery $=[\mathrm{CE} / \mathrm{CM} \times 100]$}

Where $\mathrm{CE}$ is, the experimental concentration determined from the calibration curve and CM is the spiked concentration [21].

\section{Elements analyzed}

Based on the reference studies the elements like Al (Aluminium), Cr (Chromium), Mn (Manganese), Fe (Iron), Co (Cobalt), Ni (Nickel), $\mathrm{Si}$ (Silicon), and $\mathrm{Pb}$ (Lead) were analyzed in both settled and suspended chalk dust $[2,18,19]$.

\section{Statistical analysis}

The statistical analyses were performed by using the SPSS 19.0 statistical software. Basic statistical analysis like mean, median and standard deviation were performed. Statistical associations between the variables were performed using chi square tests. The level of significance was set to be less than 0.05 .

\section{Results}

\section{Socio demographic characteristics}

A total of 50 participants were included in this study, with a mean age of $39.82 \pm 104.1$ (Mean \pm std) with an age group ranging from 20 to 57 . Female participants are dominant in the group with a mean age group of $43.21 \pm 1.87$ (Mean \pm std). Among all the participants, the participants from the age group 30-39 are overriding (Table 2).

\section{Trace element concentration in whole blood samples of teachers}

Due to lack of availability appropriate certified commercial reference materials of whole blood samples, the recovery rate was measured using known spiked concentrations of all the investigated elements ( $\mathrm{Al}$, $\mathrm{Cr}, \mathrm{Mn}, \mathrm{Fe}, \mathrm{Co}, \mathrm{Ni}, \mathrm{Si}, \mathrm{Pb}$ ). The consistency of results was confirmed by measuring the recoveries of the spiked elements to the sample concentrations. The recovery percentages of the trace elements analyzed were in the range of 70 to $96 \%$ (Table 3) indicating good accuracy, precision and validity of the method.

The geometric mean of trace elements in whole blood samples of study participants $(\mu \mathrm{g} / \mathrm{l})$ : blood aluminium 1398.9; blood chromium 39.04; blood manganese 249.6; blood iron 19499; blood cobalt 1.95; blood nickel 32.9; blood silicon 70847; blood pb 752.4. Among all the elements, the elements like Silicon (70847), Iron (19499) and Aluminum

\begin{tabular}{|c|c|}
\hline Parameter & Value \\
\hline Plasma conditions & Forward power $1500 \mathrm{~W}$ \\
\hline Plasma glass flow & $15.0 \mathrm{~L} / \mathrm{min}$ \\
\hline Carrier glass flow & $0.75 \mathrm{~L} / \mathrm{min}$ \\
\hline Dilution glass flow & $1 \mathrm{~L} / \mathrm{min}$ \\
\hline He gas flow & $4-5 \mathrm{~mL} \cdot \mathrm{min}^{-1}$ \\
\hline QP bias & $-15 \mathrm{v}$ \\
\hline Oct bias & $-18 \mathrm{v}$ \\
\hline Cell entrance & $-40 \mathrm{v}$ \\
\hline Cell exit & $-60 \mathrm{v}$ \\
\hline Deflect & $-0.8 \mathrm{v}$ \\
\hline Plate bias & $-6.0 \mathrm{v}$ \\
\hline Nebulizer type & Miramist \\
\hline Sample uptake rate & $1.5 \mathrm{~mL} / \mathrm{min}$ \\
\hline
\end{tabular}

Table1: IC-PMS operating parameters.

\begin{tabular}{|c|c|c|c|c|c|}
\hline \multirow{2}{*}{ Variables } & \multicolumn{5}{|c|}{ Distribution } \\
\hline & Mean & STD & $\mathbf{n}$ & \% & p-value \\
\hline Age & & & & & \\
\hline $20-29$ & 25.44 & 2.58 & 9 & 18 & \multirow{2}{*}{0} \\
\hline $30-39$ & 34.58 & 3.03 & 17 & 34 & \\
\hline $40-49$ & 44.18 & & 11 & 22 & \\
\hline$\geq 50$ & 52.66 & & 13 & 26 & \\
\hline Gender & & & & & \multirow{2}{*}{0.034} \\
\hline Male & 37.65 & 2.09 & 19 & 38 & \\
\hline Female & 43.21 & 1.87 & 31 & 62 & \\
\hline Years of service & & & & & \multirow{2}{*}{0.15} \\
\hline $0-10$ & 27.7 & 3.4 & 13 & 26 & \\
\hline $11-20$ & 37.92 & 6.7 & 23 & 46 & \\
\hline $21-30$ & 44.18 & 2.4 & 14 & 28 & \\
\hline
\end{tabular}

Table 2: Socio Demographic characteristics of participants.

\begin{tabular}{|c|c|c|c|c|}
\hline \multirow[b]{2}{*}{ Elements } & \multirow[b]{2}{*}{ Added $(\mu \mathrm{g} / \mathrm{L})$} & \multicolumn{2}{|c|}{ Measured mass fraction } & \multirow[b]{2}{*}{$\%$ Recovery } \\
\hline & & $\begin{array}{c}\text { Obtained } \\
\text { value }(\mu \mathrm{g} / \mathrm{L})\end{array}$ & $\begin{array}{l}\text { Spiked value } \\
(\mu \mathrm{g} / L)\end{array}$ & \\
\hline Al & 1 & 15.4 & 16.1 & 70 \\
\hline $\mathrm{Cr}$ & 1 & 0.7 & 1.6 & 90 \\
\hline$M n$ & 1 & 7.5 & 8.3 & 80 \\
\hline $\mathrm{Fe}$ & 10 & 237.7 & 238.4 & 70 \\
\hline Co & 1 & 0.95 & 1.91 & 96 \\
\hline $\mathrm{Ni}$ & 1 & 4.8 & 5.6 & 80 \\
\hline Si & 10 & 497.2 & 506.7 & 95.5 \\
\hline $\mathrm{Pb}$ & 10 & 3.51 & 10.88 & 73.7 \\
\hline
\end{tabular}

Table 3: Recovery of the elements from the spiked whole blood samples $(N=50)$.

(1398) are noticed with higher concentration in the whole blood samples of teachers. The normal value of silicon concentration in blood was not set so far [22,23]. The normal limit of Iron in the human blood [24] is 65 to $175 \mu \mathrm{g} / \mathrm{dl}$ in males and 50 to $170 \mu \mathrm{g} / \mathrm{dl}$ in females. This indicates that the concentration of iron is high in teachers. Few studies suggest that normal range of aluminum in human blood is $0-6 \mathrm{mcg} / \mathrm{dl}[25]$ which indicates that the aluminum concentration in the teachers was beyond the normal limit. The normal limit of manganese in human blood is 
Citation: Ramprasad S, Maruthi YA (2017) Whole Blood Characterization in School Teachers with Reference to Chalk Sticks. J Environ Anal Toxicol 7: 465. doi: 10.4172/2161-0525.1000465

Page 3 of 5

$4-15 \mu \mathrm{g} / \mathrm{l}[26]$. The concentration of manganese in teachers is $249 \mu \mathrm{g} / \mathrm{l}$, which is beyond the blood normal limit. The normal limit of lead in blood [27] is $10 \mu \mathrm{g} / \mathrm{dl}$. The concentrations of chromium [28] and Cobalt [29] in teachers are beyond the normal range i.e. $2-3 \mu \mathrm{g} / \mathrm{l}$ and $<1 \mu \mathrm{g} / \mathrm{l}$ (Table 4).

\section{Relationship between trace element concentrations among different age groups}

The trace elemental concentration of whole blood samples based on different age groups was mentioned in Table 5 . In the present study age groups did not noticed any statistical difference.

\section{Comparison of trace elements concentrations between the genders}

The trace elemental concentration of whole blood samples in teachers were mentioned in Table 6 . There no significant differences

\begin{tabular}{|c|c|c|c|c|c|}
\hline Elements & \multicolumn{5}{|c|}{ Teachers } \\
\hline & Min $(\mu \mathrm{g} / \mathrm{l})$ & Max $(\mu \mathrm{g} / \mathrm{l})$ & Mean $(\mu \mathrm{g} / \mathrm{l})$ & Median $(\mu \mathrm{g} / \mathrm{l})$ & $\mathrm{SD}(\mu \mathrm{g} / \mathrm{l})$ \\
\hline $\mathrm{Al}$ & 852.3 & 1811.3 & 1398.9 & 1472.8 & 315.8 \\
\hline $\mathrm{Cr}$ & 25.8 & 48.03 & 39.04 & 39.8 & 5.04 \\
\hline $\mathrm{Mn}$ & 201.9 & 262.4 & 249.6 & 257.6 & 15.6 \\
\hline $\mathrm{Fe}$ & 16267 & 20594 & 19499 & 20213 & 1143 \\
\hline $\mathrm{Co}$ & 0.02 & 3.67 & 1.95 & 2.11 & 1.08 \\
\hline $\mathrm{Ni}$ & 14.8 & 40.8 & 32.9 & 36.4 & 7.9 \\
\hline $\mathrm{Si}$ & 16245 & 92182 & 70847 & 81397 & 24385 \\
\hline $\mathrm{Pb}$ & 101.8 & 996.6 & 752.4 & 838.9 & 233 \\
\hline
\end{tabular}

Table 4: Trace elemental concentrations in whole blood samples of teachers. were noticed between the genders. Almost all the elements were noticed at similar concentrations in genders.

\section{Relationship between the trace element concentration and years of service}

The influence of trace element concentration on years of service was mentioned in Table 7 . The trace element concentration revealed a positive association between the years of service. The trace elemental concentration was increased with the years of service, which clearly indicates the chalk is the prime reason for the higher concentration of trace elements in whole blood samples in teachers.

\section{Discussion}

Till today there is no proper standard method for accurate assessment of trace elements in human body. As per the literature review to assess the low dose chronic exposure of heavy metals, blood sample is considered as good indicator and it can reveal the recent comprehensive information of various elements in the body. In the present random sampling method was followed for the collection of blood samples. Basing on the literature studies alkali dilution method was chosen as best suitable method for dilution of blood samples [20]. Due to lack of proper standard reference materials the recovery percentages was analyzed for the qualitative data [22]. From the report a total of eight elements were observed in the blood samples of teachers. Among the eight elements the Silicon, Aluminum, Iron was noticed with higher concentrations in teachers. The reason for the higher concentration of silicon is blood is respirable silica dust, which occurs from the chalk dust. Zhang et al. reported that silicon exposure from the chalk dust causing oxidative damages to Alveolar macrophages, $\mathrm{He}$ also reported that deposition of the silicon in lungs might cause silicosis $[8,9]$. Unfortunately there is no standard limit of Silicon in blood was reported so far. The normal limit of Iron in the human blood is 65 to

\begin{tabular}{|c|c|c|c|c|c|}
\hline \multirow{2}{*}{ Elements } & \multicolumn{5}{|c|}{ Age groups of teachers } \\
\hline & $20-29(\mathrm{~N}=9)$ & $30-39(\mathrm{~N}=17)$ & $40-49(\mathrm{~N}=11)$ & $\geq 50(\mathrm{~N}=13)$ & $P$-value \\
\hline $\mathrm{Al}$ & $912.7 \pm 49.4$ & $1693.7 \pm 101.3$ & $1585.4 \pm 98.1$ & $1308.1 \pm 199.4$ & 0.028 \\
\hline $\mathrm{Cr}$ & $31.1 \pm 3.6$ & $43.1 \pm 2.1$ & $40.5 \pm 2.0$ & $39.1 \pm 1.5$ & 0.034 \\
\hline $\mathrm{Mn}$ & $224.3 \pm 11.1$ & $260 \pm 1.5$ & $257.1 \pm 5.2$ & $252.2 \pm 7.0$ & 0.175 \\
\hline $\mathrm{Fe}$ & $17446 \pm 815.3$ & $20352 \pm 176.7$ & $20183.5 \pm 150.5$ & $19619 \pm 524.9$ & 0.086 \\
\hline Co & $0.34 \pm 0.27$ & $3.1 \pm 0.3$ & $2.53 \pm 0.2$ & $1.53 \pm 0.57$ & 0.023 \\
\hline $\mathrm{Ni}$ & $17.9 \pm 1.6$ & $39.6 \pm 0.8$ & $37.4 \pm 1.2$ & $33.3 \pm 3.4$ & 0.045 \\
\hline Si & $25616 \pm 7713$ & $89967 \pm 1088$ & $86325 \pm 3540$ & $72113 \pm 12467$ & 0.098 \\
\hline $\mathrm{Pb}$ & $320.3 \pm 160.4$ & $941 \pm 31.2$ & $880.9 \pm 33.4$ & $777.9 \pm 65.7$ & 0.136 \\
\hline
\end{tabular}

Table 5: Trace element concentration in different age groups.

\begin{tabular}{|c|c|c|c|}
\hline \multirow{2}{*}{ Elements } & \multicolumn{2}{|c|}{ Gender } \\
\cline { 2 - 4 } & Male & $1411.7 \pm 313.8$ \\
\hline $\mathrm{Al}$ & $1411.3 \pm 303.1$ & $39.6 \pm 4.3$ \\
\hline $\mathrm{Mn}$ & $38.6 \pm 4.8$ & $250.3 \pm 14.2$ \\
\hline $\mathrm{Fe}$ & $251.2 \pm 13.9$ & $19634 \pm 1076$ \\
\hline $\mathrm{Co}$ & $19514 \pm 1181.7$ & $2.0 \pm 1.0$ \\
\hline $\mathrm{Ni}$ & $1.9 \pm 1.0$ & $33.2 \pm 7.9$ \\
\hline $\mathrm{Si}$ & $33.5 \pm 7.6$ & 0.016 \\
\hline $\mathrm{Pb}$ & $72824 \pm 24304$ & 0.034 \\
\hline
\end{tabular}

Table 6: Trace elements in different gender groups. 
Citation: Ramprasad S, Maruthi YA (2017) Whole Blood Characterization in School Teachers with Reference to Chalk Sticks. J Environ Anal Toxicol 7: 465. doi: 10.4172/2161-0525.1000465

Page 4 of 5

$175 \mu \mathrm{g} / \mathrm{dl}$. The concentration of Iron in blood samples of teachers were beyond the normal limit. The Iron toxicity causes the local and systemic effects. $10-20 \mathrm{mg} / \mathrm{kg}$ of iron causes the local irritation of gastrointestinal tracts and which triggers symptoms like nausea, vomiting, Diarrhea and abdominal pain. The chronic exposure to Iron i.e. more than $60 \mathrm{mg} / \mathrm{kg}$ can cause the organ damage and tissue malfunction. Even a lethal dose of Iron $(200-250 \mathrm{mg} / \mathrm{kg})$ can cause death. The daily intake of aluminum is $0-0.6 \mathrm{mg} / \mathrm{kg}$ [30]. The normal limit of aluminum in blood is $0-6 \mathrm{mcg} /$ $\mathrm{dl}$. The previous studies reported that aluminum can damage the human brain [31]. The normal limit of manganese in human blood is $4-15 \mu \mathrm{g} / \mathrm{l}$. The concentration of manganese in teachers is $249 \mu \mathrm{g} / \mathrm{l}$ which is beyond the normal limit. The exposure to manganese causes the behavioral changes and nervous system disorders [32]. The concentrations of chromium and cobalt were also beyond the normal limit. The relation of trace element concentration with socio demographic variables like gender, age and years was also studied. There is no statistical difference between the gender was noticed with trace element concentration. As per literature, it is noticed that gender did not influence the concentration in metals [33]. The same was repeated in the present study. About the influence of age on trace element concentration, there were more reports Bohnen reported that $\mathrm{Mn}, \mathrm{Cu}, \mathrm{Zn}$ showed differences with age and he also mentioned that the elements like $\mathrm{Pd}, \mathrm{Cd}, \mathrm{Cr}, \mathrm{Ni}, \mathrm{Se}$ and $\mathrm{Al}$ did not showed any differences with age [34]. Kristiansen et al. reported that only arsenic showed significant difference with the age group [35]. Jiqiang et al. reported that age did not show any difference in trace element concentration [36]. In the present study also the age did not showed any difference in trace element concentration. The years of service has shown a significant difference in all the elements. The concentrations of elements were increased with the increase in years of service. The elements like Silicon, Iron, Aluminium were noticed in elevated concentrations in teachers. So far there is no studies were conducted on blood samples of teachers.

This study is first of its kind to report the toxicity of usage of chalk sticks in teachers. The results of the present study were compared with the trace element concentrations of chalks (Table 8). From the past studies, it is observed that the elements like Iron, silicon and Aluminum are dominant. The results of the present study also showed the higher concentrations of Iron, Silicon, and Aluminum. Therefore, it is confirmed that the chalk is the prime reason for the higher concentrations of these elements in teacher. This study did not attempt in the control group to correlate with the teachers. Even with this limitation, it is proved that chalk is main reason for the trace elements concentrations in teachers.

\section{Conclusion}

The concentrations of trace elements like Aluminum (Al), Chromium (Cr), Manganese (Mn), Iron (Fe) Cobalt (Co), Nickel (NI), Silicon $(\mathrm{Si})$ and $\mathrm{Lead}(\mathrm{Pb})$ were analyzed using ICPMS. The overall concentrations of all the elements except silicon were beyond the normal limits of blood. For silicon there is so standard normal limit. Among all the elements Silicon, Iron and Aluminum were noticed with higher concentrations. Relation between the trace elements concentration and demographic variables like age, gender, and years of service was also studied. The gender and age did not show any significant difference in trace element concentration. The positive association was noticed between the trace element concentration and years of service. Almost all the elements noticed with increasing concentration with increasing

\begin{tabular}{|c|c|c|c|c|}
\hline \multirow{2}{*}{ Elements } & \multicolumn{4}{|c|}{ Years of service } \\
\cline { 2 - 5 } & $\mathbf{0 - 1 0}(\mathbf{N}=\mathbf{1 3})$ & $\mathbf{1 1 - 2 0} \mathbf{( N = 2 3 )}$ & $\mathbf{2 1 - 3 0}(\mathbf{N}=\mathbf{1 4})$ & \multirow{2}{*}{ P-value } \\
\cline { 2 - 5 } & Mean $\pm \mathbf{S T D}$ & Mean $\pm \mathbf{S T D}$ & Mean \pm STD & 0.092 \\
\hline $\mathrm{Al}$ & $957.5 \pm 97.6$ & $1472.8 \pm 170.2$ & $1683.2 \pm 93.1$ & 0.035 \\
\hline $\mathrm{Cr}$ & $32.9 \pm 4.0$ & $40.10 \pm 1.6$ & $43.2 \pm 1.67$ & 0.046 \\
\hline $\mathrm{Mn}$ & $229.7 \pm 12.4$ & $255.9 \pm 5.0$ & $260.3 \pm 1.39$ & 0.025 \\
\hline $\mathrm{Co}$ & $17879.6 \pm 945.3$ & $19981.2 \pm 301.3$ & $20367.5 \pm 176.5$ & 0.179 \\
\hline $\mathrm{Ni}$ & $0.480 \pm 0.35$ & $2.0 \pm 0.5$ & $3.12 \pm 0.35$ & 0.057 \\
\hline $\mathrm{Si}$ & $21.0 \pm 4.8$ & $35.87 \pm 1.91$ & $39.7 \pm 0.72$ & 0.026 \\
\hline $\mathrm{Pb}$ & $33844.8 \pm 14858.6$ & $81610.0 \pm 5603.7$ & $89828.4 \pm 1255.6$ & 0.075 \\
\hline
\end{tabular}

Table 7: Trace elemental concentration in teachers with different years of service.

\begin{tabular}{|c|c|c|c|c|c|c|c|c|c|}
\hline \multirow{2}{*}{ S.No } & \multicolumn{9}{|c|}{ Elements (Mean values of chalk samples in $\mu \mathrm{g} / \mathrm{kg}$ ) } \\
\hline & Al & $\mathrm{Cr}$ & Mn & $\mathrm{Fe}$ & Co & $\mathrm{Ni}$ & $\mathrm{Si}$ & $\mathrm{Pb}$ & Ref \\
\hline 1 & 2177 & 138.4 & 801.8 & 334.8 & 223.7 & 31.4 & 516.2 & 197.8 & [18] \\
\hline 2 & 3596 & 230.5 & 1061 & 516 & 213.9 & 57.8 & 360.6 & 217 & [18] \\
\hline 3 & 32514285 & 88500 & 3938000 & 1590000 & - & 34000 & 94985000 & 48000 & [37] \\
\hline 4 & 2100000 & - & - & 100000 & - & - & 2000079 & - & [2] \\
\hline 5 & 252700 & 8300 & - & 740000 & - & 22700 & 4454000 & - & [19] \\
\hline 6 & - & 2430 & - & - & 685 & 2000 & - & 12262 & [5] \\
\hline 7 & - & 110300 & 85500 & - & 10000 & 22200 & - & 37500 & [12] \\
\hline
\end{tabular}

Table 8: Comparison of results found in this study with previous studies. 
Citation: Ramprasad S, Maruthi YA (2017) Whole Blood Characterization in School Teachers with Reference to Chalk Sticks. J Environ Anal Toxicol 7: 465. doi: 10.4172/2161-0525.1000465

Page 5 of 5

in years of service. The results of the study were compared with studies on trace element concentrations in chalk. The similarity in elevated concentrations of Silicon, Iron and Aluminum proved that chalk is the prime reason for the elevated concentrations of trace elements in teachers. Hence, it is concluded that exposure to chalk causes health hazards in teachers and it is suggested that teachers should follow safety measures to reduce chalk dust related occupational health hazards in teachers.

\section{Acknowledgements}

The authors are grateful to the centre for studies on Bay of Bengal laboratory, Andhra University for permitting us to carry out the ICPMS analysis in thei laboratory. The authors are also grateful to the GITAM University for providing necessary lab facilities.

\section{References}

1. Kovess-Masféty V, Sevilla-Dedieu C, Rios-Seidel C, Nerrière E, Chee CC (2006) Do teachers have more health problems? Results from a French cross sectional survey. BMC Public Health 6:101.

2. Fayez Hassan M (2011) Investigation of lecturers chalk by X-Ray Florescence and Fast Neutron Activation Analysis. Proceedings of 8th conference on nuclear and particle physics 207-212.

3. Majumdar D, William SP (2009) Chalk dust fall during classroom teaching: Particle size distribution and Morphological characteristics. Environ Monit Assess 148: 343-351.

4. Majumdar D, Gajghate DG, Pipalatkar P, Chalapati Rao CV (2012) Assessment of air borne fine particulate matter and particle size distribution in settled chalk dust during writing and dusting exercises in classroom. Indoor Built Environment 21: 541-551.

5. Corazza M, Zauli S, Pagnoni A (2011) Contact dermatitis caused by metals in black board chalk: A case report. Act Derm Venereo 436-437.

6. Nikam KD, Hikrani MA (2013) Effect of chalk dust on peak expiratory flow rate in school teachers. Int $\mathrm{J}$ Med Health Sci 2: 407-409.

7. Viadya P, Kashyap S, Sharma S, Gupta P, Mohapatra PR (2007) Respiratory symptoms and Pulmonary function tests in school teachers of shimla. Lung India 24: 6-10.

8. Zhang Y, Yang Z, Feng Y, Li R, Zhang Q, et al. (2015) Effect of coarse chalk dust particles $(2.5-10 \mu \mathrm{m})$ on respiratory burst and oxidative stress in alveolar macrophages. Environ Sci poll Res Int 22: 12450-12457.

9. Zhang YX, Yang ZH, Zhang QX, Li RJ, Geng H, et al. (2015) Chemical compositions and Effect of chemiluminescence of AMs in vitro of chalk dusts. Chinese Chem Lett 26: 157-159.

10. Thareja P, Jayjee GK, Dawan I, Single P (2011) Comparative analysis of PowerPoint and black board teaching methodologies. Curr Trends Informationtechnol 1: 8-15.

11. Dyer C (1996) The improvement of primary school quality in India: success and failures of Operation black board. Edinburgpapers in south asian studies 4 .

12. Nasir SJ (1996) Minerology, Petrography and manufacturing of good quality black board chalk.Qatar University Sci J 16: 325-331.

13. Thakker M, Shukla P, Shah DO (2016) Surface and colloidal properties of chalk: a novel approach using surfactants to convert normal chalks into dustless chalks. Colloids and Surfaces A: Physicochemical and Engineering Aspects 480: 236-244.

14. Raith L, Jaeger K (1986) The nickel content of chalk--cause of contact dermatitis? Contact Dermatitis 14: 61.

15. Fromme H, Diemer J, Dietrich S, Cyrys J, Heinrich J, et al. (2008) Chemical and morphological properties of particulate matter (PM10.PM2.5) in school classrooms and outdoor air. Atmos Environ 42: 597-660.

16. Tran DT, Alleman LY, Coddeville P, Galloo JC (2012) Elemental characterization and source identification of size resolved atmospheric particles in French classrooms. Atmos Environ 54: 250-259.

17. Ivenenko NB, Ivenenko AA, solovyev ND, Zeimal AE, Novolotoskii DV, et al. (2013) Biomonitoring of 20 trace elements in blood and urine of occupationally exposed workers by sector field Inductive coupled mass spectroscopy. Talanta 116: 764-769.

18. Maruthi YA, Lakshmana das N, Ramprasad S, Ram SS, Sudarshan M (2015) Trace elemental analysis of school chalk using Energy Dispersive X-ray Florescence Spectroscopy (ED-XRF) 1675: 030088.

19. Maruthi YA, Ramprasad S, Lakshman Das S (2016) Trace elemental characterization of chalk dust and their health risk assessment. Biol Trace Element Res 1-9.

20. Lu Y, Kippler M, Harari F, Grandér M, Palm B, et al. (2015) Alkali dilution of blood samples for high throughput ICPMS analysis-Comparison with acid digestion. Clin Biochem 48: 140-147.

21. Chudzinska M, Debska A, Baralkiewicz D (2012) Method validation for determination of 13 elements in honey samples by ICPMS. Accred Qual Assur 17: 65-73.

22. Sun L, Yu Y, Huang T, An P, Yu D, et al. (2012) Associations between ionomic profile and metabolic abnormalities in human population. PLoS One 7: 1-10.

23. Maria Carmen Alpoim (2006) Metal ions in biology and medicine. Jhon libbey euro text publishers, 9: 570 .

24. Holm G (2015) Serum Iron Test. Health Line News Letters.

25. Mick West (2012) Normal and Toxic Levels of Aluminum in Blood Serum.

26. The Environmental Protection Agency (EPA) Toxic Substances Portal Manganese.

27. Lab Tests Online (2016) Lead Testing Uncovered Flint, Michigan's Water Contamination Crisis.

28. Environmental Health and Medicine Education (2008) Chromium Toxicity Clinical Assessment - Laboratory Tests.

29. Detecting cobalt toxicity. Monitoring metallic prosthetic implant wear. Mayo Medical Laboratories.

30. Nordberg GF, Fowler BA, Nordberg M (2015) Handbook on toxicology of metals. ( $4^{\text {th }}$ Edn). Elsevier.

31. Chen TJ, Cheng HM, Wang DC, Hung HS (2011) Non lethal aluminum maltolate can reduce brain derived neurotrophic factor induced arc expression through interpreting the ERK signaling in SH-SY5Y neuroblastoma cells. Toxicol Lett 200: 67-76.

32. Crossgrove J, Zheng W (2004) Manganese toxicity upon overexposure. NMR Biomed 17: 544-553.

33. Błażewicz A, Klatka M, Astel A, Partyka M, Kocjan R (2013) Differences in trace metal concentrations ( $\mathrm{Co}, \mathrm{Cu}, \mathrm{Fe}, \mathrm{Mn}, \mathrm{Zn}, \mathrm{Cd}, \mathrm{Ni}$ ) in whole blood, plasma and urine of obese and non obese children. Biol Trace Element Res 155: 190-200.

34. Bohnen N, Jolles J, Degenaar CP (1994) Levels of trace elements in blood in healthy aging subjects. Z Gerontol 27: 324-327.

35. Kristiansen J, Christensen JM, Iversen BS, Sabbioni E (1997) Toxic trace element reference levels in blood and urine: influence of gender and lifestyle factors. Sci Total Environ 204: 147-160.

36. Li J, Cen D, Huang D, Li X, Xu J, et al. (2014) Detection and analysis of 12 heavy metals in blood and hair sample from a general population of Pearl River Delta area. Cell Biochem Biophysics. 70: 1663-1669. 